\title{
Integrating Conservation and Financial Objectives on Private Rangelands in Northern Colorado: Rancher and Practitioner Perceptions
}

\author{
Megan Gutwein ${ }^{1}$ and Joshua H. Goldstein ${ }^{2}$ \\ Authors are ${ }^{1}$ Graduate Student and ${ }^{2}$ Assistant Professor, Department of Human Dimensions of Natural Resources, Colorado State University, Fort \\ Collins, CO 80523, USA.
}

\begin{abstract}
Payments for ecosystem services and other approaches seek to expand conservation outcomes from working ranches in rangeland systems. Making these strategies attractive to ranchers and effective in achieving conservation goals requires information that is largely lacking about the human dimensions of aligning conservation, agricultural, and financial objectives on working ranches. This exploratory study addressed this knowledge gap about perceived strategies, barriers, and opportunities by interviewing a purposive sample of 23 ranchers and natural resource practitioners (e.g., government agencies, conservation nonprofits) involved in a collaborative stakeholder group in Larimer County, Colorado. Interviewees' responses demonstrated a wide range of potential strategies for ranchers to adopt, yet their discussion of ranch-scale and regional concerns demonstrated the multiple interlinked ecological, financial, and social factors that pose challenges for mainstreaming opportunities. All interviewees expressed interest in developing a regional payment for ecosystem services program, seeing an opportunity to simultaneously support ranchers and improve conservation stewardship. However, substantial concerns were expressed regarding possible restrictions to the ranch operation, profitability, and other management and legal factors that would diminish attractiveness to ranchers. Our findings suggest that characteristics of our study system, including proximity to urban areas and the presence of a collaborative stakeholder group, contribute importantly to the opportunities and challenges perceived by interviewees. Furthermore, interviewees' responses highlighted how factors beyond the ranch-scale can affect the viability of ranch business strategies to achieve conservation and agricultural objectives. Future research with representative populations across rangeland systems in the American West and in contexts with and without collaborative groups will build constructively upon this exploratory study.
\end{abstract}

Key Words: costs, environmental markets, incentives, payments for ecosystem services, revenue

\section{INTRODUCTION}

Profound changes in population size, land use, agricultural and energy markets, and other factors are transforming rangeland ecosystems across the United States and globally (Millennium Ecosystem Assessment 2005). These factors are driving landuse change (e.g., exurban development; Theobald 2001) and impacting the livelihoods of private landowners who steward over half of the 770 million acres of rangelands in the United States (US Department of Agriculture [USDA] Forest Service 2011).

Ranchers, as stewards of private rangelands, have conventionally derived ranch-related income largely from their livestock operations, rather than from conservation practices that produce a broader array of ecosystem services (e.g., carbon sequestration, water quality; Goldstein et al. 2011). For ranchers who implement conservation practices, such practices may be a burden on a ranch's financial portfolio rather than a positive contribution (Didier and Brunson 2004).

\footnotetext{
Research was funded in part by a fellowship through the Center for Collaborative Conservation at Colorado State University.

Correspondence: Megan Gutwein, Dept of Human Dimensions of Natural Resources, Colorado State University, Fort Collins, C0 80523, USA. Email: meganchr2@yahoo. com
}

Manuscript received 7 November 2011; manuscript accepted 25 October 2012

(c) 2013 The Society for Range Management
New incentives, broadly termed payments for ecosystem services (PES) or environmental markets, may provide an opportunity for ranchers to align conservation, agricultural, and financial objectives in land management (Engel et al. 2008; Daily et al. 2009). A recent report from the USDA Office of Environmental Markets and EcoAgriculture Partners on the "Farm of the Future" (which encompasses working farms, ranches, and forests) profiled five case studies of private landowners receiving PES, while still earning agricultural income (EcoAgriculture Partners 2011). For example, one working farm is receiving revenue from wetland mitigation banking, hunting permits, water quality enhancement, and row crops. In examining what PES may mean for rangelands and ranchers in the future, it is important to acknowledge the many important publicly funded programs through which ranchers are already being compensated for ecosystem services. Examples include the National Resources Conservation Service costshare programs and a variety of tax incentives (e.g., for conservation easements).

To examine the plausibility of these types of working ranch business strategies, it is important to understand ranchers' motivations for ranching, challenges they face, income sources and cost-reduction strategies supporting ranches today, and new financial opportunities being developed. Ranchers are motivated by multiple factors internal and external to their ranching operation, with frequently cited motivations being related to family tradition, lifestyle, connection to the land, and amenity values such as scenic beauty and recreation (Smith and 
Martin 1972; Bartlett et al. 1989; Liffmann et al. 2000; Peterson and Coppock 2001; Rowe et al. 2001; Gosnell and Travis 2005). Previous work has found that profitability is a factor but not necessarily the primary motivation in ranch decisions (Smith and Martin 1972; Gentner and Tanaka 2002). Nonetheless, financial concerns are integral to influencing land management decisions that impact the livestock operation and ecosystem-service provision (purposely or incidentally). These concerns are more prevalent when ranchers rely on their land for their livelihoods (Rowe et al. 2001).

Ranchers face multiple threats that may compel them to exit the livestock business and sell their land. Development changes the character of the landscape and can lead to the perceived inevitability of urbanization (Liffmann et al. 2000). Furthermore, as development displaces livestock operations, regional suppliers may shut down due to the loss of a "critical mass" of producers (Rowe et al. 2001). The lack of successors is another challenge facing the aging population of agriculturalists (Gale 2003; Brunson and Huntsinger 2008). Additional perceived threats include, for example, increasing grazing fees, reductions in public grazing allotments, increasing public lands recreation, the presence of threatened and endangered species, and wilderness designations (Coppock and Birkenfeld 1999; Liffmann et al. 2000; Rowe et al. 2001; Gentner and Tanaka 2002; Sulak and Huntsinger 2007).

Ranchers' financial strategies supplement livestock-related income with revenue generating and cost-reduction sources, such as hunting leases, government landowner assistance programs (e.g., Environmental Quality Incentives Program), hospitality services, and compensation for conservation easements (e.g., tax credits). Off-ranch income is another component supporting rancher livelihoods (Jackson-Smith et al. 2005).

As noted earlier, PES represents a new incentive-based mechanism to reward landowners for providing ecosystem services that benefit the public at-large (Goldstein et al. 2011). While PES is not widespread in rangeland systems (DutillyDiane 2007), pilot programs illustrate the approach. Through the Florida Ranchlands Environmental Services Project in the northern Everglades, ranchers are being paid for improving onranch nutrient retention and water storage (Bohlen et al. 2009). Similarly, in the Fort Hood Recovery Credits System in Texas, ranchers are being paid for protecting and restoring habitat for the endangered Golden-cheeked warbler (Dendroica chrysoparia; Sorice and Conner 2010).

Here, we report on an exploratory, place-based study in Larimer County, Colorado, of a ranching and conservation collaborative encompassing private landowners, government agencies, conservation nonprofits, and other groups who are working to sustain the agricultural and conservation values of this landscape into the future. We investigated the perceptions of ranchers and natural resource practitioners related to the challenges and opportunities for integrating conservation, agricultural, and financial objectives on private ranches. We addressed multiple questions: 1) What are the revenue generating and cost-reduction strategies currently supporting working ranches, and how are conservation practices linked to these strategies? 2) What are the major challenges facing ranches, and what are current or potential future strategies to address these challenges? 3) What are the barriers and opportunities for integrating PES into ranch operations? We report on key themes that emerged from our interviews, while also examining how our exploratory case study relates to the broader context of private rangeland management in the United States.

\section{METHODS}

\section{Study System}

Larimer County, located in north central Colorado, encompasses 682000 ha (Wallace et al. 2008) and is the seventh largest county in Colorado based upon its population of 299630 residents in 2010 (US Census Bureau 2010). Land ownership is approximately $60 \%$ public and $40 \%$ private (Ernst and Wallace 2008). The region has a $100+$ yr history of ranching that continues today amidst multiple pressures, particularly urban and exurban growth. Larimer County is part of the Laramie Foothills Mountains-to-Plains habitat corridor, a 57000-ha conservation-production landscape on the Colorado-Wyoming border. The landscape includes primarily shortgrass prairie, foothills shrublands, and riparian habitat vegetation communities. In an effort to conserve undeveloped land for ranching, biodiversity, public recreation, and other ecosystem services, public and private entities have partnered to improve resource stewardship and to protect over 20230 ha (Resnik et al. 2006). The Mountains-to-Plains project contains an active stakeholder collaborative called the Laramie Foothills Advisory Committee (LFAC) that includes participation from private landowners, public agencies (city, county, state, and federal), The Nature Conservancy's Colorado chapter, local land trusts, researchers, and a local economy nonprofit.

\section{Study Design}

The target population for interviews was ranchers and natural resource practitioners associated with the LFAC and the Mountains-to-Plains project. To identify potential interviewees, we worked with a key informant who has played a lead role with the LFAC for $27 \mathrm{yr}$. The informant provided a list of 37 individuals, which served as our sampling frame, including 30 ranchers representing small, medium, and large producers, and seven natural resource practitioners from public agencies and nongovernmental organizations (NGOs) actively working with ranchers. We chose a purposive sample (Neuman 2003) because of this study's exploratory nature and the LFAC's expressed interest in participating; this presented the opportunity to interview ranchers and practitioners working together to address the region's challenges in sustaining working ranches and achieving rangeland conservation goals.

The initial contact for each of the 37 individuals was made by the key informant or a representative from the Colorado Cattlemen's Association to briefly explain the study by a trusted person. If the potential interviewee expressed interest, the researchers then followed up to schedule an in-person meeting. We completed 23 interviews (62\% response rate) including 16 ranchers and seven practitioners between August 2010 and February 2011. Three ranchers declined to participate after being contacted by the initial representative, and 11 ranchers 
did not respond after leaving three phone messages at various times of day. Given that our data analysis (described below) showed no new themes emerging, we decided to discontinue making additional phone calls (Strauss and Corbin 1998).

We collected information through a topic-driven semistructured interview followed by a short end-of-interview survey to capture participants' concluding thoughts. We pilot tested the instrument with the key informant to ensure that questions were clear, comprehensive, and reasonable in length. Feedback resulted in a minimally revised question set. The major topics covered were: revenue-generating and cost-reduction strategies currently supporting working ranches; current and expected future challenges facing ranchers; and strategies to address these challenges to achieve conservation, agricultural, and financial objectives, including a particular focus on PES.

\section{Analysis}

We audio recorded interviews with permission, and for the one participant not granting permission, we took detailed notes by hand. We transcribed audio-recorded interviews and typed the notes from the one nonrecorded interview to enable coding in NVivo data analysis software (QSR International Pty Ltd 2008). We used a three-level coding procedure of open, axial, and selective coding (Strauss and Corbin 1998; Neuman 2003). Open coding was performed on a line-by-line basis during the first pass through each transcript. We identified codes as themes emerged, and open coding provided a signal of data saturation, with fewer new codes emerging with each successive interview (Strauss and Corbin 1998). Axial coding involved making a second pass through the transcripts to identify broader themes, which were then related back to codes and subcategories. Codes were iteratively re-examined for appropriateness and clarity. Selective coding involved scanning the data, codes, and themes for illustrative and comparative cases, as well as connecting related themes. The analysis included qualitative assessment of the themes emerging from participants' responses, as well as quantitative assessment through frequency counts of the number of participants and type (e.g., rancher or practitioner) who discussed each issue.

\section{RESULTS}

Our results for this exploratory study describe the perceptions of ranchers and practitioners affiliated with our study system. We describe the breadth of responses and themes, while noting that each interviewee's perceptions characterize a different subset of the total responses.

For the 16 ranchers interviewed, age ranged from 38 to $80 \mathrm{yr}$ with a median age of $62 \mathrm{yr}$. Ten ranchers were male, and six were female. Thirteen ranchers had active cattle herds, and three leased pasture to other ranchers, though previously had their own herds. In terms of ranch history, six ranches had been in the family for multiple generations (at least $40 \mathrm{yr}$ ), six had been under the same ownership for at least $20 \mathrm{yr}$ but less than $40 \mathrm{yr}$, and four had been under the current operation for less than 20 yr. Four ranchers only grazed on deeded land, while the remaining 12 used a combination of deeded and public and/or private leased land. Using size categories relevant to the study system as defined by the key informant, three ranches were small (0 to 404 ha of deeded and/or leased acres), seven ranches were medium (405 to $4855 \mathrm{ha}$ ), and six ranches were large ( $\geq 4856$ ha).

For the seven practitioners interviewed, age ranged from 33 to $62 \mathrm{yr}$, with a median age of $46 \mathrm{yr}$. Four practitioners were male, and three were female. Interviewees worked for the City of Fort Collins Natural Areas Program, City of Fort Collins Water Utility, Larimer County Department of Natural Resources, The Nature Conservancy's Colorado chapter, the USDA Forest Service, the USDA Natural Resource Conservation Service, and the Colorado Division of Wildlife. Practitioners' professional experience ranged from 7 to $35 \mathrm{yr}$, and they held their current position for 2 to $30 \mathrm{yr}$.

\section{Current Ranch Operation}

Ranchers reported drawing upon different combinations of income from cattle and other ranch-related or off-ranch sources. Only $25 \%$ of ranchers identified cattle as their main income source. Three ranchers reported selling grassfed beef to local buyers, though this accounted for only a small portion of total income. For the $94 \%$ of ranchers who drew upon ranch-related income beyond cattle products or grazing leases, the main sources were selling additional products beyond cattle, including hay, crops, chickens, pigs, goats, sheep, and moss rock, as well as earning income for leases for hunting access, cell towers, and oil drilling. There was also an individual example of a ranch selling hospitality services and limited residential building lots as part of a conservation development. Seventy-five percent of ranchers reported earning most of their income from off-ranch sources, including employment, real estate sales or rentals, and financial investments. Forty-four percent of ranchers have a conservation easement over part or all of their property. Thirty-eight percent of ranchers reported participating currently in one or more government landowner assistance program (e.g., Environmental Quality Incentives Program and Conservation Stewardship Program), which provides cost-share and in some cases rental payments.

Interviewees identified a range of current management practices that they perceive to be contributing to land or water stewardship on working ranches in the study region. The most common responses by ranchers and practitioners were rotational livestock grazing $(83 \%)$, weed control through mechanical or chemical means $(65 \%)$, water development in multiple pastures $(61 \%)$, and fencing off riparian areas $(30 \%)$. Interviewees reported benefits from these practices related to increasing carrying capacity, controlling weeds, and fire mitigation. As noted by one rancher, these practices (with the exception of fencing off riparian areas) are amongst a set of relatively "standard" practices employed by most ranchers in the study region. Examples of other management practices reported by less than $25 \%$ of interviewees included installing erosion control structures and wildlife-friendly fencing, improving irrigation efficiency, restoring native vegetation and managing for wildlife habitat, conducting prescribed burns, and changing to a late spring calving season (rather than the more common winter season) to enable calves to graze longer on rangeland resources than hay. 


\section{Perceived Challenges Facing Ranchers}

Interviewees discussed a wide range of challenges facing ranching operations in the study region, with themes emerging in five general categories: ecological, financial, legal and policy, personal, and social. Ecological challenges were issues related to natural resources, natural disasters, climate, or wildlife. The two most frequently mentioned concerns were water scarcity $(57 \%)$ and weed control $(26 \%)$, with each highlighted more prominently by ranchers than practitioners in the context of how these factors might constrain their livestock operation. Examples of other perceived ecological challenges included impacts related to wildlife damage, wildfires, climate change, disease, and environmental impacts from the use of petroleum products (e.g., oil and gas).

Financial challenges were related to the economics of operating a ranch, including costs, operational resources, and markets. The most cited issue acknowledged by ranchers and practitioners was rising input costs $(87 \%)$, which included items such as feed prices, transportation costs, and equipment. One rancher noted, "Labor and feed's our big expenses. And we're not, we're not high on the salary side, I mean (laughs), you don't come here to get rich. Labor and feed are big costs, actually." Similarly, ranchers and practitioners emphasized the overarching challenge of ranching not being profitable $(83 \%)$, noting that many ranchers in the region earn little to no profit from livestock. Ranchers more than practitioners emphasized concerns about taxes (57\%), focusing specifically on inheritance taxes, property taxes, and the need to remain in an agricultural tax bracket because of the lower assessment value, as well as general concerns about future tax increases. Examples of other perceived financial challenges included operational scale related particularly to having enough land to raise a profitable number of cattle, challenging regional and national economic conditions, insurance expenses (e.g., health, crop), livestock market prices, and effective marketing strategies.

Legal and policy challenges were related to perceived institutional factors affecting ranchers' ability to run a profitable operation. The most cited issue by ranchers and practitioners was how regulatory constraints were perceived to constrain the ranch operation in terms of management and business practices $(74 \%)$. One rancher noted, "We have a staff position now called Human Resources... back in the 90s, that never was the case, but it takes a person now, at least part time, to keep track of the wage requirements and so forth." A closely related concern also raised by ranchers and practitioners was "red tape" or bureaucratic obstacles $(57 \%)$, particularly related to the paperwork and other requirements of ranchers to participate in potentially beneficial programs or undertake certain management practices. As one rancher noted regarding PES, "I think if it's beneficial and it doesn't create more paperwork and nightmares, I might consider it." Examples of other perceived legal or policy challenges included concerns about liability for allowing public access (e.g., injuries), Endangered Species Act restrictions, the appropriateness of conservation easements and restrictions that come with easements, and changes in ownership and land use related to exurban development and the perception of public ownership taking land out of production.
Personal challenges were related to ranchers' individual situations and lifestyle, and therefore separable from broader economic or regional factors. The greatest perceived challenge by ranchers and practitioners was the hard work and long hours required to run a working ranch $(78 \%)$. One rancher noted, “... it's a full time job. I mean, you don't have a hobby... we don't play golf, we don't bowl, you don't have time." Related to time pressure was concern about potential interference by outsiders in ranch operations $(57 \%)$. One rancher stated, "There's just so many things that ... to generate any money or to do something that people would pay you actually to do interferes with the day to day operations." Concerns about risks and uncertain outcomes from implementing operational changes $(52 \%)$ and uncertainty about the future $(48 \%)$, particularly in the context of fluctuating market prices, were also prominent responses. Ranchers and practitioners noted general suspicion by some ranchers of the government and how this reduces willingness to participate in government programs $(39 \%)$. One rancher said, "You never know what the government's gonna do. The state could change... the rules, or how they fund it and everything." Examples of other perceived personal challenges included discomfort with or lack of heirs, knowledge gaps, and limited mentions of suspicion regarding other actors including NGOs, neighbors, oil companies, hobby ranchers, and researchers.

Social challenges were related to ranchers' interactions with the broader community. The most cited issue by ranchers and practitioners was regional factors, such as the changing social character of the region as neighboring ranches sell to developers and decreasing regional availability of agricultural services, compelling ranchers to sell their land to developers $(70 \%)$. Related were concerns about unfavorable perceptions of cattle grazing by some members of the public $(52 \%)$ and conflicts with neighbors $(48 \%)$, both discussed particularly in the context of regional population growth and the fact that many newcomers are unfamiliar with livestock operations. Examples of other perceived social challenges included potential conflicts between different constituencies (e.g., ranchers, recreationists, and conservationists); negative visual impacts of residential development, cell towers, and other additions to the landscape; the challenges of decision-making by multiple landowners for cross-boundary stewardship; reductions in lands available for grazing leases, regional cattle processors and other services; and concerns by ranchers that new conservation payment programs, including PES, might be viewed as "welfare" or "handouts."

\section{Potential Rancher Strategies to Address Challenges}

Ranchers and practitioners described current or potential future strategies to achieve conservation, agricultural, and financial objectives in the face of multiple challenges. These strategies were related to three general categories: reducing costs, enhancing revenue, and building regional capacity to support ranch-related services and market development.

Interviewees identified three specific strategies currently in use to reduce costs, though none of these is yet widespread across ranches in the study system. The first strategy was reducing marketing costs for beef products through direct sales to consumers by word of mouth, email, private auction, or 
locating a private buyer who contracts for many cattle, rather than going through a conventional cattle auction. The second strategy was changing calving season from the common regional practice of winter calving to spring calving that two ranchers discussed as helping reduce cattle feed costs because the native range now provided most of the necessary feed when animal nutritional requirements are greatest. Additional cost savings were also reported related to reduced fuel and labor costs resulting from reduced need to cut and bale hay. The third strategy was allowing cattle to graze on windrow hay cuts to save on baling costs. Ranchers and practitioners also discussed the general need to continue to find ways to assist ranchers with equipment and management practices that have relatively high upfront costs to improve the ranch operation and deliver enhanced conservation benefits. Assistance for fencing, water development in multiple pastures, and grassland restoration were specifically mentioned.

Ranchers and practitioners also identified a range of ideas for enhancing revenue to support working ranches in the study system. While some of these are already being captured on a few ranches, none are yet widespread, and many remain suggested future opportunities. The most cited responses were payments for rangeland carbon offset credits (39\%) and payments for water quality and/or quantity enhancements resulting from improved ranch management practices $(39 \%)$, both indicative of interest in PES more broadly. Interviewees also mentioned PES related to riparian habitat, wetland mitigation, and pollinator habitat conservation. Related to water payments, one rancher said, "It seems to me... a number of utilities in the region are concerned about having to install new treatment equipment... it's going to be quite costly and if farmers and ranchers can help them avoid those costs by making sure their runoff from their spread is not contributing to the problem and getting reimbursed for that some way." Another major revenue category was lease opportunities, including wind energy, hunting or other recreational access, extraction of oil, natural gas, or minerals, and cell or radio tower installations. Examples of additional opportunities included integrating management of livestock beyond cattle, selling to value-added beef or specialty crop (e.g., lavender) markets, providing hospitality, guiding, or wellness services, clustered residential development, and timber sales, particularly in the context of beetle-kill.

Interviewees also discussed how regional characteristics and activities could help build capacity to support working ranches and conservation efforts. Ranchers and practitioners discussed their perception of the region's changing ranch culture $(30 \%)$. This was primarily discussed as ranchers being more open and willing to try new management practices and business strategies (e.g., switching from winter to spring calving season, raising grass-fed cattle) rather than implementing only the traditional cow-calf model. Interviewees also noted that stakeholder collaboration and communication (e.g., through the LFAC) provided the opportunity for mutually beneficial partnerships between landowners and other organizations (26\%). One practitioner said, "I don't think there's many places in the country that you can... find the interaction and the cooperation between varied entities. From a rancher to a conservation organization to local governments... there's been a lot of buy in and I think it's been great because people have maybe opened their eyes to where an organization or government might have been threatening or scary ... turns out to be a partner.” Finally, interviewees discussed efforts in the region to support the expansion of local markets for grassfed and other value-added beef products $(22 \%)$. One practitioner noted that a key component of a successful local market would be a leader to organize ranchers and create a market in such a way to overcome concerns about connecting supply and demand.

\section{Perspectives on PES}

All ranchers and practitioners expressed potential interest in developing a regional PES program. Interviewees' perceived most promising aspects of PES were the potential to enhance conservation stewardship in the region $(52 \%)$, increase rancher income $(35 \%)$, and relatedly, contribute to preserving the ranching lifestyle $(22 \%)$ and to diversifying income sources $(13 \%)$. Other perceived promising aspects included land stewards being recognized for providing ecosystem services, directly linking conservation and rancher income, opportunities to improve grazing conditions, perceived efficient use of limited conservation dollars, expand public and landowner awareness of ecosystem services, support development of local markets for livestock and ecosystem services, and establish the precedent of conditionality-meaning payments are only made conditional upon ecosystem services being provided.

Ranchers and practitioners also raised many perceived concerns about a regional PES program. Most cited was the concern about possible restrictions to the ranch operation from entering into a PES contract, particularly how constraints might negatively impact a ranch's overall financial situation $(74 \%)$. Interviewees also raised concerns about whether PES contracts would be profitable and, even if yes, the degree to which they could help solve the larger financial challenges facing working ranches (39\%). One rancher stated, "It seems like the payment, you know, if you're talking a few bucks an acre or whatever, it isn't worth the interference, so to speak." Another rancher noted, "[PES] may not be enough to keep a lot of ranches from being subdivided.”

Another overarching concern was whether ranchers would be able to increase ecosystem-service provision in a way that would qualify them to receive payments-a concept termed additionality (22\%). Interviewees expressed the perception that some ranchers already provide ecosystem services (e.g., already stewarding rangelands in healthy condition), and therefore were unsure the degree to which services could be enhanced to qualify for payment. One rancher said, "It's going to be very difficult to get somebody to pay for what we're already providing, and what most ranches are providing, actually."

Multiple issues were raised specifically in the context of carbon markets. Nearly half of ranchers but no practitioners expressed personal suspicion of carbon markets, questioning the stability and appropriateness of contracts and the funding behind them. One rancher said, "If it's a long term contract, and you have a relationship with a company, then I would always worry about them changing the rules of the game." Related were concerns about how entering into a carbon contract would limit management options. One rancher noted, "I was concerned about the limits signing that kind of contract would put on us as far as grazing practices. Because they were 
very specific... you needed to set up a grazing plan and you needed to stick to it and if you deviated from it ... you'd lose payments and you'd have to return the money." More broadly, four ranchers (but no practitioners) questioned the legitimacy of carbon markets, referring to them as "schemes" or "fiction." Some ranchers were also unsure if they had carbon to sell, associating carbon markets more closely with forests than rangelands.

Beyond the issues discussed above, other perceived concerns about PES included: lack of knowledge about how PES works, transparency and trust amongst potential parties in a PES contract; bureaucratic obstacles that could make PES participation burdensome; unknown risks and costs of a new program; time and energy required to participate in a new program; possible public perception that PES is a welfare payment to ranchers; and a question as to whether a regionalscale program was most needed in the broader global conservation context.

Interviewees identified multiple needs to inform PES development in the region. Generally, practitioners identified needs more than ranchers. Suggestions on general needs included details on how a program would be structured, examples of existing PES programs, examples of local ecosystem services that could be provided, participation rules and responsibilities, and guidance on monitoring, verification, and reporting requirements. Some interviewees suggested the importance of designing a program that would only require ranchers to make relatively simple changes to management practices, and that would also minimize regulations and paperwork. Financial needs related to analysis of participation costs, benefits, and risks, strategies to minimize ranchers' costs, and an expressed desire for PES payments to have greater certainty in amounts and timing than livestock markets. The main reported legal and policy need was having term contracts. One rancher said, "If there were limits ... on how long we need to participate, it was something that could be renewed, like every 3 years or something, I think that would make it more encouraging." Additional needs included running a pilot program to test and refine the approach and to pave the way for other participants, launching a public awareness campaign, and building trust between key stakeholders in PES design and implementation.

\section{DISCUSSION}

Our results came from a purposive sample of ranchers and practitioners connected to a collaborative stakeholder group in Larimer County, Colorado. In examining the implications of our exploratory research, it is important to consider the types of rangeland systems to which our results may be generalizable, as well as our study's limitations. Notable characteristics of our system include close proximity to urban areas, the presence of a collaborative group supporting working ranches and landscape-scale conservation efforts, and the presence of a landgrant university (Colorado State University). In the larger context of the Colorado Front Range, our study system is also in close proximity to a major national park (Rocky Mountain National Park) and a major international airport in Denver. Examples of other locations that share many of these characteristics, and therefore may be regions where our results are relatively more applicable include, for example, working ranches in the Phoenix-to-Tucson corridor in Arizona, the greater Bay Area in California, and around Reno, Nevada, Boise, Idaho, and Albuquerque, New Mexico (Brunson and Huntsinger 2008).

Proximity to urban areas may open up certain income opportunities for ranchers such as off-ranch employment, local consumers demanding value-added beef products and hospitality or guiding services, clustered residential development, and possibly some types of PES in the future (e.g., payments for watershed services where the rural area is in the source watershed of a downstream urban area; Stanton et al. 2010). At the same time, these potential financial opportunities are countered by the land-use pressures they contribute to that compel ranchers to exit the livestock business and sell their land for development. Furthermore, proximity to urban areas is not a positive driver for all income opportunities. For example, the attractiveness of payments for carbon sequestration is driven by market prices, rangeland carbon sequestration rates, and program eligibility rules unrelated to urban amenities.

The presence of the collaborative group in our study system seems to play, based upon interviewees' responses, a disproportionately important role in fostering trust and cooperation, stimulating innovation, and building cross-sector constituencies to create practical opportunities for ranchers. For example, the impetus to explore PES development came from the collaborative group, and this group is also supporting the development of local markets for value-added beef products, amongst other efforts. While we did find some minor differences in responses by ranchers and practitioners (e.g., ranchers but not practitioners raised suspicion of carbon markets), we did not find any systematic differences that suggest distinctly contrasting understandings of issues nor divergent paths in terms of how to address issues. This may be attributable, in part, to the fact that many interviewees are already discussing together the region's broader concerns and opportunities. While collaboration raises issues in how to find a constructive path forward, many of the challenges facing ranchers and rural communities (e.g., urban-rural divide, public demands for environmental benefits) cut across economic sectors and stakeholder groups (Brunson and Huntsinger 2008). Accordingly, addressing these challenges will likely benefit from, if not require, formal stakeholder engagement processes.

Our focus on private ranches is directly related to the conservation of rangeland systems and values, given that over half of US rangelands are privately managed (USDA Forest Service 2011). In urban-proximate areas, rangeland fragmentation and habitat degradation due to exurban development and other human impacts have been found to negatively impact biodiversity and ecosystem services (Maestas et al. 2003; Havstad et al. 2007). Financial strategies that support working ranches and enhance conservation stewardship are one important component of a larger strategy to prevent further rangeland fragmentation and to improve landscape-scale conservation outcomes (Goldstein et al. 2006; Bohlen et al. 2009). Furthermore, finding ways to guide exurban development in ecologically sensitive ways will be important to achieving conservation goals, given that development pressure is likely to continue (Pejchar et al. 2007). Related to PES, 
concerns have been raised about making sure that a program incentivizes holistic ecological function rather than maximizing single-service delivery (e.g., carbon sequestration) with unintended impacts on other services (Redford and Adams 2009).

Few ranchers whom we interviewed reported livestock being their main income source, a result also reported by others (e.g., Gentner and Tanaka 2002; Jackson-Smith et al. 2005). For ranchers who are largely or exclusively dependent upon livestock, incorporating new revenue streams may be challenging, particularly if there are tradeoffs with the livestock operation (Goldstein et al. 2011). Furthermore, the economics of the livestock business are highly dynamic. While cattle market prices are currently high, increases in input costs (e.g., feed and fuel prices) have raised concerns about how to manage and reduce the costs of livestock grazing and the overall ranch operation (Campbell 2011). Relatedly, cost-share assistance through Farm Bill programs or other sources may be key to making it financially attractive to ranchers to adopt new conservation practices (Batie 2009). At the regional scale, discussion by our interviewees corroborated previous research reporting that community development can create peripheral problems for ranchers such as regulatory changes (e.g., noise ordinances; Berry and Plaut 1978; Rowe et al. 2001) and loss of a "critical mass" of producers (Rowe et al. 2001). When faced with policy changes such as decreased access to public land or increased grazing fees, ranchers may sell the ranch before diversifying (Coppock and Birkenfeld 1999; Peterson and Coppock 2001).

Enhancing ecosystem-service revenue opportunities for working lands is a widely discussed need (EcoAgriculture Partners 2011) that was also emphasized by our interviewees. For such opportunities to come to fruition, a key question is: where will funding sources to buy ecosystem services come from? For carbon offsets, the most widely available opportunity used to be the Chicago Climate Exchange's Sustainably Managed Rangeland Soil Carbon Sequestration Offset Project protocol, up until the Exchange closed in 2010. While other opportunities exist (Peters-Stanley et al. 2011), there remains a funding void for rangeland carbon offset projects. In the context of payments for watershed services, an important driver is the adoption of "green" rather than "grey" infrastructure approaches as a more cost-effective solution (e.g., funding improved watershed management practices instead of, or in combination with, equipment upgrades at a water treatment plant; Stanton et al. 2010). How widespread a phenomenon this represents remains to be seen, but there is a growing focus on understanding the water-related needs of municipal utilities and water-intensive companies (e.g., bottling companies), and determining ways in which working lands stewardship can help to costeffectively meet these needs (Hanson et al. 2008).

Interviewees discussed multiple criteria, which broadly corroborate findings in the literature, that would need to be addressed for ranchers to consider participating in PES. First, easy access to descriptive information is critical, because problems can arise if landowners are not fully informed about program rules (Corbera et al. 2007; Petheram and Campbell 2010). Second, several participants discussed the need for success stories from existing programs or from pilot projects in our study region in order to undertake management changes and participate in a future PES program. This request fits with Rogers (1995) theory that innovations are more likely to be adopted after there are positive results. Third, ranchers' concern about whether they would be in a position to adopt new management practices to generate enhanced ecosystemservice benefits relates directly to the debate about additionality being a factor contributing to PES legitimacy (Wunder et al. 2008). As such, PES programs are increasingly targeting both "positive" additionality (improvements above baseline) and "avoided loss" (preventing reductions that would occur under a business-as-usual scenario; e.g., avoided grassland conversion or avoided deforestation). Finally, the closure of the Chicago Climate Exchange highlights the uncertainty of PES opportunities (Gosnell et al. 2011). While all markets are volatile, the newness of the PES approach may be unattractive to risk-averse ranchers.

Future research with an expanded geography and in more representative rangeland contexts would build constructively on this exploratory study to provide more robust and generalizable results. Two questions for expansion are: first, how can optimal strategies be developed to address cost and revenue components in ways that maximize ranchers' profitability, reduce ranchers' exposure to risks, and deliver public environmental benefits? And second, how do ranch-scale and regional characteristics affect the relative viability of PES and other financial strategies for working ranches that connect to conservation objectives in rangeland systems? Integrating financial information with ecological, social, and political analysis can inform the development of working ranch business strategies that meet the needs of ranchers and the broader public in delivering agricultural and conservation values from rangeland systems.

\section{IMPLICATIONS}

Ranchers and practitioners who participated in our exploratory study expressed diverse perceptions about the barriers and opportunities of developing strategies to align conservation, agricultural, and financial objectives on working ranches in the study system. While we recognize (as noted earlier) the limited representativeness of our purposive sample population, we propose three overarching findings relevant to rangeland management and policy. First, the breadth of challenges and financial strategies reported by even our limited sample population suggests that there is no one-size-fits-all solution for working ranches. Accordingly, care must be taken to understand and align strategies that fit with the motivations, opportunities, and constraints of individual ranchers, and which furthermore support regional conservation objectives. Second, our results suggest that factors beyond the ranch scale (e.g., presence of a collaborative group, proximity to urban areas) will affect the ability of an individual ranch to succeed (or not) with strategies targeting conservation, agricultural, and financial outcomes. Therefore, analysis of lessons learned and management and policy recommendations must be defined around relevant ranch-scale and regional characteristics. Finally, stakeholders exploring ecosystem services in rangeland contexts should first consider a set of general questions as described in Maczko and Hidinger (2008). In the specific 
context of PES, the information we gathered from ranchers and practitioners suggests at least three linked questions to address, which are also consistent with broader discussions of PES in the literature: what ecosystem service(s) would a PES program focus on, and how would this contribute to rangeland conservation goals? What would be the motivations for buyers and sellers to participate? And how would programmatic structure affect ability to participate? PES could open up valuable new opportunities to align conservation and economic incentives for working ranches in rangeland systems, but it is not a silver-bullet solution, as indicated by feedback we obtained from our interviewees. Rather, ranchers, practitioners, researchers, and others must work together to determine PES feasibility and to design programs that are contextually appropriate.

\section{ACKNOWLEDGMENTS}

We sincerely thank the ranchers and practitioners who participated in interviews for their time and insights. We also thank M. FernandezGimenez, R. Reid, and three anonymous reviewers for constructive comments on earlier manuscript drafts.

\section{LITERATURE CITED}

Bartlett, E. T., R. G. Taylor, J. R. McKean, and J. G. Hof. 1989. Motivation of Colorado ranchers with federal grazing allotments. Journal of Range Management 42:454457.

BATIE, S. S. 2009. Green payments and the US Farm Bill: information and policy challenges. Frontiers in Ecology and the Environment 7:380-388.

BERRY, D., AND T. Plaut. 1978. Retaining agricultural activities under urban pressures: a review of land use conflicts and policies. Policy Science 9:153-178.

Bohlen, P. J., S. Lynch, L. Shabman, M. Clark, S. Shukla, and H. Swain. 2009. Paying for environmental services from agricultural lands: an example from the northern Everglades. Frontiers in Ecology and the Environment 7:46-55.

Brunson, M. W., and L. Huntsinger. 2008. Ranching as a conservation strategy: can old ranchers save the new West? Rangeland Ecology \& Management 61:137147.

CampBel, E. 2011. Shrinking cattle herd signals beef rising to record, higher Wendy's costs. Bloomberg. Available at: http://www.bloomberg.com/news/2011-07-21/ shrinking-cattle-herd-signals-beef-rising-to-record-higher-wendy-s-costs.html. Accessed 26 October 2011.

Coppock, D. L., And A. H. BiRkenfeld. 1999. Use of livestock and range management practices in Utah. Journal of Range Management 52:7-18.

Corbera, E., N. Kosoy, and M. M. Tuna. 2007. Equity implications of marketing ecosystem services in protected and rural communities: case studies from Meso-America. Global Environmental Change 17:365-380.

Dally, G. C., S. Polasky, J. Goldstein, P. M. Kareiva, H. A. Mooney, L. L. Pejcahr, T. H. Ricketts, J. Salzman, and R. Shallenberger. 2009. Ecosystem services in decision making: time to deliver. Frontiers in Ecology and the Environment 7:21-28.

Didier, E. A., And M. W. Brunson. 2004. Adoption of range management innovations by Utah ranchers. Journal of Range Management 57:330-336.

Dutilly-Diane, C., N. McCarthy, F. Turkelboom, A. Bruggeman, J. Tiedemann, K. Street, and G. SerRA. 2007. Could payments for environmental services improve rangeland management in Central Asia, West Asia and North Africa? Washington, DC, USA: International Food Policy Research Institute. CAPRi Working Paper No. 62.33 p.

EcoAgriculture Partners. 2011. Farm of the future. Available at: http://www. ecoagriculture.org/farmofthefuture/index.php. Accessed 2 August 2011.

Engel, S., S. Pagiola, and S. Wunder. 2008. Designing payments for environmental services in theory and practice: an overview of the issues. Ecological Economics 65:663-674. doi: 10.1016/j.ecolecon.2008.03.011
ERnst, T., and G. N. Wallace. 2008. Characteristics, motivations, and management actions of landowners engaged in private land conservation in Larimer County, Colorado. Natural Areas Journal 28:109-120.

Gale, H. F. 2003. Age-specific patterns of exit and entry in U.S. farming, 1978-1997. Review of Agricultural Economics 25:168-186.

Gentner, B. J., And J. A. Tanaka. 2002. Classifying federal public land grazing permittees. Journal of Range Management 55:2-11.

Goldstein, J. H., G. C. Dally, J. B. Friday, P. A. Matson, R. L. Naylor, and P. Vitousek. 2006. Business strategies for conservation on private lands: Koa forestry as a case study. Proceedings of the National Academy of Sciences 103:1014010145.

Goldstein, J. H., C. K. Presnall, L. López-Hoffman, G. P. Nabhan, R. L. Knight, G. B. RUYLE, AND T. P. ToomBs. 2011. Beef and beyond: paying for ecosystem services on western US rangelands. Rangelands 33(5):4-12.

Gosnell, H., N. Robinson-Maness, and S. Charnley. 2011. Engaging ranchers in marketbased approaches to climate change mitigation: opportunities, challenges, and policy implications. Rangelands 33(5):20-24.

Gosnell, H., and W. R. Travis. 2005. Ranchland ownership dynamics in the Rocky Mountain West. Rangeland Ecology \& Management 58:191-198.

Hanson, C., J. Ranganathan, C. Iceland, and J. Finisdore. 2008. The corporate ecosystem services review: guidelines for identifying business risks and opportunities arising from ecosystem change. Available at: http://pdf.wri.org/ corporate_ecosystem_services_review.pdf. Accessed 13 October 2011.

Havstad, K. M., D.P.C. Peters, R. Skaggs, J. Brown, B. Bestelmeyer, E. Fredrickson, J. HerRick, AND J. WriGht. 2007. Ecological services to and from rangelands of the United States. Ecological Economics 64:261-268.

Jackson-Smith, D., U. Kreuter, and R. S. Krannich. 2005. Understanding the multidimensionality of property rights orientations: evidence from Utah and Texas ranchers. Society and Natural Resources 19:587-610.

Liffmann, R. H., L. Huntsinger, and L. C. Forero. 2000. To ranch or not to ranch: home on the urban range? Journal of Range Management 53:362-370.

MACZKo, K., AND L. Hidinger [EDS.]. 2008. Sustainable rangelands ecosystem goods and services. Fort Collins, CO, USA: Colorado State University, Warner College of Natural Resources. Sustainable Rangelands Roundtable Monograph No. 3. $111 \mathrm{p}$.

Maestas, J. D., R. L. Knight, and W. C. Gilgert. 2003. Biodiversity across a rural landuse gradient. Conservation Biology 17:1425-1534.

Millennium Ecosystem Assessment. 2005. Ecosystems and human well-being: synthesis. Washington, DC, USA: Island Press. $137 \mathrm{p}$.

Neuman, W. L. 2003. Social research methods: qualitative and quantitative approaches. 5th ed. Boston, MA, USA: Pearson Education, Inc. 584 p.

Pejchar, L., P. M. Morgan, M. R. Caldwell, C. Palmer, and G. C. Dally. 2007. Evaluating the potential for conservation development: biophysical, economic, and institutional perspectives. Conservation Biology 21:69-78.

Peterson, R., and D. L. Coppock. 2001. Economics and demographics constrain investment in Utah private grazing lands. Journal of Range Management 54:106114.

Peters-Stanley, M., K. Hamilton, T. Marcello, and M. Sjardin. 2011. Back to the future: state of the voluntary carbon markets 2011. Available at: http://www. forest-trends.org/ foresttr/publication_details.php?publicationID=2828. Accessed 13 October 2011.

Petheram, L., and B. M. Campbell. 2010. Listening to locals on payments for environmental services. Journal of Environmental Management 91:1139-1149.

QSR International PTy LTD. 2008. NVivo 8 Qualitative Data Analysis Software. Version 8. Doncaster, VIC, Australia: International Pty Ltd.

Redford, K. H., and W. M. Adams. 2009. Payment for ecosystem services and the challenge of saving nature. Conservation Biology 23:785-787.

Resnik, J., G. Wallace, M. Brunson, and J. Mitchell. 2006. Open spaces, working places. Rangelands 28(5):4-9.

Rogers, E. 1995. Diffusion of innovations. 4th ed. New York, NY, USA: Free Press. $518 \mathrm{p}$.

Rowe, H. I., E. T. Bartlett, and L. E. Swanson, JR. 2001. Ranching motivations in two Colorado counties. Journal of Range Management 54:314-321.

SMith, A. H., AND W. E. Martin. 1972. Socioeconomic behavior of cattle ranchers, with implications for rural community development in the West. American Journal of Agricultural Economics 54:217-225. 
Sorice, M. G., and J. R. Conner. 2010. Predicting private landowner intentions to enroll in an incentive program to protect endangered species. Human Dimensions of Wildlife 15:77-89.

Stanton, T., M. Echavarria, K. Hamilton, and C. Ott. 2010. State of watershed payments. Available at: http://www.ecosystemmarketplace.com/pages/dynamic/ resources.library.page.php?page_id $=7599 \&$ section=water_market\&eod $=1$. Accessed 13 October 2011.

Strauss, A., AND J. Corbin. 1998. Basics of qualitative research: techniques and procedures for developing grounded theory. 2nd ed. Thousand Oaks, CA, USA: SAGE Publications, Inc. $312 \mathrm{p}$.

Sulak, A., And L. Huntsinger. 2007. Public land grazing in California: untapped conservation potential for private lands? Rangelands 29(3):9-12.
Theobald, D. M. 2001. Land-use dynamics beyond the American urban fringe. Geographical Review 91:544-564.

US Census Bureau. 2010. State and County Quick Facts: Larimer County, C0. Available at: http://quickfacts.census.gov/qfd/states/08/08069.html. Accessed 13 April 2011.

USDA Forest Service. 2011. Rangelands. Available at: http://www.fs.fed.us/ rangelands/whoweare/index.shtml. Accessed 25 August 2011.

Wallace, G. N., D. M. Theobald, T. ERnst, and K. King. 2008. Assessing the ecological and social benefits of private land conservation in Colorado. Conservation Biology 22:284-296.

Wunder, S., S. Engel, AND S. PAGiola. 2008. Taking stock: a comparative analysis of payments for environmental services programs in developed and developing countries. Ecological Economics 65:834-852. 